\author{
WOJCIECH KĘPKA ${ }^{1 *}$, JACEK ANTONKIEWICZ ${ }^{1}$, CZESŁAWA JASIEWICZ ${ }^{1}$, \\ FLORIAN GAMBUŚ ${ }^{1}$, ROBERT WITKOWICZ ${ }^{2}$ \\ ${ }^{1}$ University of Agriculture in Kraków, Faculty of Agriculture and Economics, \\ Department of Agricultural and Environmental Chemistry, Av. Mickiewicza 21, 31-120, Kraków, Poland \\ ${ }^{2}$ University of Agriculture in Kraków, Faculty of Agriculture and Economics, Institute of Plant Production, \\ Av. Mickiewicza 21, 31-120, Kraków, Poland
}

\title{
The effect of municipal sewage sludge on the chemical composition of spring barley
}

\begin{abstract}
Due to the fact that soils in Poland are mostly light soils, there is a need to improve their physical, chemical and biological properties. In addition, as a result of the decrease in the number of farm animals, a decrease in production of natural fertilizers can be observed. Low production of natural fertilizers speaks in favor of agricultural use of municipal sewage sludge in Poland. Municipal sewage sludge is composed of large quantities of macronutrients necessary for plants. This waste also contains significant amounts of organic substance. Chemical properties, including a high content of nitrogen, phosphorus, and often calcium, speak in favor of environmental use of municipal sewage sludge. Increasing requirements with respect to environmental protection cause the necessity to assess the effects of using organic waste for fertilization. In a farm located in the commune of Iwanowice (Małopolska province), municipal sewage sludge was applied under spring barley cultivation. The soil on which municipal sewage sludge was applied was classified into the category of heavy soils with neutral reaction. When assessing the content of available nutrients $(\mathrm{P}, \mathrm{K}, \mathrm{Mg})$ in the soil, their low content was determined. After application of municipal sewage sludge in a dose of $24 \mathrm{Mg}$ fresh matter per hectare, which corresponded to $5.34 \mathrm{Mg} \mathrm{DM} \cdot \mathrm{ha}^{-1}$, under spring barley, beneficial changes in chemical properties of the soil were observed. An increase in soil abundance in organic carbon and total nitrogen was observed, as well as an increase in the content of available forms of phosphorus, potassium and magnesium. Based on the results of the conducted chemical analyses, it was established that biomass of spring barley fertilized with sewage sludge contained more macronutrients $(\mathrm{N}, \mathrm{P}, \mathrm{K}, \mathrm{Na}, \mathrm{Ca}$ and $\mathrm{Mg}$ ), which improved its feed value. The field experiment showed that application of municipal sewage sludge increased uptake of macronutrients by spring barley.
\end{abstract}

Keywords: spring barley, municipal sewage sludge, macronutrients, content, uptake, elements relationship

\section{INTRODUCTION}

The dynamic development that has been observed in recent years in the field of technical-sanitary infrastructure, particularly in the sewage system, as well as in sewage treatment technology itself, is the cause of the growing number of sewage treatment plants in Poland (Environment 2015). Hence, the problem of municipal sewage sludge management is intensifying (Bień et al. 2011, Kelessidis and Stasinakis 2012, Environment 2015). In 2014, the amount of municipal sewage sludge generated in Poland amounted to 556 thousand tons of dry matter, and the mass of sludge produced is growing systematically year by year (Environment 2015). In connection with such a high production of municipal sewage sludge that meets chemical and sanitary criteria, there is a possibility to increase its share in environmental management. Chemical and biological composition of sewage sludge has decisive influence on the way it is used and managed (Act on waste 2012, Regulation 2015, Wie- czorek and Fraczek 2013). In 2014, the use of municipal sewage sludge in agriculture in Poland amounted to over $19 \%$, in land reclamation $-4 \%$, whereas more than $5.6 \%$ (in relation to the total amount of sludge produced) was disposed (Environment 2015).

In agriculture, the main sources of nutrients for plants include mineral, natural (manure) and organic (compost) fertilizers, as well as mineral-organic wastes allowed to be applied to soils. Municipal sewage sludge is also more and more often used as a potential source of macronutrients (Ahmed et al. 2010, Wieczorek 2013). Using sewage sludge in agriculture as an unconventional fertilizer may take place when it does not pose a risk to soil quality, which includes chemical and sanitary pollution (Ahmed et al. 2010, Petruzzelli et al. 2015, Regulation 2015). Municipal sewage sludge has a great variability of its chemical composition. A high content of heavy metals which can deteriorate soil fertility and have an adverse effect on crop yielding may be a considerable problem (SorianoDisla et al. 2014, Wieczorek 2013). 
Sludge coming from rural sewage treatment plants that receive mainly domestic wastewater can be useful in agriculture (Wieczorek and Frączek 2013). In general, such municipal sewage sludge does not contain excessive quantities of heavy metals and is abundant in macronutrients, hence it is recommended to be used in agriculture to fertilize cultivated plants (BaumanKaszubska and Sikorski 2008, Alvarenga et al. 2015). In this aspect, municipal sewage sludge is a substitute for organic and mineral fertilizers. Due to high abundance in organic matter and nutrients, agricultural use of municipal sewage sludge appears to be substantiated in environmental and economic respects (Flis-Bujak et al. 1986, Fytili and Zabaniotou 2008).

The aim of the undertaken research was to assess the effect of municipal sewage sludge on soil chemical properties as well as on chemical composition and uptake of macronutrients by spring barley.

\section{MATERIALS AND METHODOLOGY OF THE RESEARCH}

\section{Soil and municipal sewage sludge}

The research on agricultural use of municipal sewage sludge was carried out under field experiment conditions, on two production fields (1 ha each) located in Iwanowice Włościańskie in the commune of Iwanowice, Małopolska province.

Basic chemical properties of the soil and municipal sewage sludge are provided in Table 1. The soil on which the field experiment was set up was classified into brown soils, and in terms of granulometric composition - into silt loam, and it contained: $13 \%$ sand, 53\% silt, 34\% clay (Systematyka gleb Polski 2011). The soil had a neutral reaction, and the content of available forms of $\mathrm{P}, \mathrm{K}$ and $\mathrm{Mg}$ was very low (Table 1). Heavy metal content in the soil did not exceed acceptable values at agricultural use of municipal sewage sludge (Regulation 2015).

Municipal sewage sludge, as organic waste with catalogue number 190805 (Catalogue of waste 2014) came from the sewage treatment plant in the commune of Iwanowice. The sludge was stabilized and hygienized with burnt lime. The sewage sludge was applied once on the surface of the experimental plot, then mixed with the topsoil $(0-25 \mathrm{~cm})$. In the municipal sewage sludge used in the experiment, no acceptable levels of microbiological pollution were exceeded (Regulation 2015).
TABLE 1. Physicochemical properties of soil and municipal sewage sludge

\begin{tabular}{|c|c|c|c|}
\hline Parameter & Unit & Soil & $\begin{array}{l}\text { Sewage } \\
\text { sludge }\end{array}$ \\
\hline Fraction 2-0.05 mm & \multirow[t]{6}{*}{$\%$} & 13 & - \\
\hline Fraction $0.05-0.002 \mathrm{~mm}$ & & 53 & - \\
\hline Fraction $<0.002 \mathrm{~mm}$ & & 34 & - \\
\hline Dry matter & & - & 22.23 \\
\hline$\underline{\mathrm{pH}(\mathrm{H} 2 \mathrm{O})}$ & & 7.15 & 9.14 \\
\hline $\mathrm{pH}(\mathrm{KCl})$ & & 6.95 & - \\
\hline Organic matter & $\mathrm{g} \cdot \mathrm{kg}^{-1} \mathrm{DM}$ & 20.95 & 554.0 \\
\hline $\mathrm{Cr}$ & \multirow[t]{7}{*}{$\mathrm{mg} \cdot \mathrm{kg}^{-1} \mathrm{DM}$} & 14.65 & 8.45 \\
\hline $\mathrm{Zn}$ & & 28.25 & 602.5 \\
\hline $\mathrm{Pb}$ & & 15.20 & 25.34 \\
\hline $\mathrm{Cu}$ & & 7.45 & 73.62 \\
\hline $\mathrm{Cd}$ & & 0.34 & 0.626 \\
\hline $\mathrm{Ni}$ & & 11.80 & 5.63 \\
\hline $\mathrm{Hg}$ & & 0.030 & 0.416 \\
\hline $\mathrm{N}$ total & \multirow[t]{6}{*}{$\mathrm{g} \cdot \mathrm{kg}^{-1} \mathrm{DM}$} & 1.11 & 22.30 \\
\hline P total & & 0.12 & 3.65 \\
\hline $\mathrm{K}$ total & & 6.3 & 2.5 \\
\hline $\mathrm{Na}$ total & & 2.3 & 1.1 \\
\hline Ca total & & $\overline{16.5}$ & 98.7 \\
\hline $\mathrm{Mg}$ total & & 0.8 & 4.8 \\
\hline $\mathrm{P}$ available & \multirow[t]{3}{*}{$\mathrm{mg} \cdot \mathrm{kg}^{-1} \mathrm{DM}$} & 12.6 & - \\
\hline $\mathrm{K}$ available & & 22.5 & - \\
\hline Mg available & & 28.2 & - \\
\hline
\end{tabular}

\section{Scheme and conditions of conducting the field experiment}

The experimental design comprised two treatments. The control treatment (1) was fertilized only with mineral fertilizers in the amount of 60:50:70 kg NPK. Nitrogen fertilizer was applied in the form of urea $(46 \% \mathrm{~N})$, phosphorus fertilizer - in the form of triple superphosphate $\left(46 \% \mathrm{P}_{2} \mathrm{O}_{5}\right)$, and potassium was applied in the form of potassium chloride $\left(50 \% \mathrm{~K}_{2} \mathrm{O}\right)$.

Research treatment 2 was fertilized with municipal sewage sludge, at a dose of $5.34 \mathrm{Mg} \cdot \mathrm{ha}^{-1} \mathrm{DM}$, which corresponded to $24 \mathrm{Mg}$ of fresh matter. The municipal sewage sludge was applied in the autumn and distributed with a manure spreader, and then pre-winter plowing was done. In total, $118 \mathrm{~kg} \cdot \mathrm{ha}^{-1}$ nitrogen $(\mathrm{N})$, $19.5 \mathrm{~kg} \cdot \mathrm{ha}^{-1}$ phosphorus $(\mathrm{P})$, and $13.5 \mathrm{~kg} \cdot \mathrm{ha}^{-1}$ potassium $(\mathrm{K})$ were introduced to the soil with the dose of 5.34 $\mathrm{Mg} \cdot \mathrm{ha}^{-1} \mathrm{DM}$. The amount of the sewage sludge dose applied under spring barley corresponded with the nitrogen requirement of this plant. It is assumed that utilization of nitrogen from sewage sludge by cultivated plants amounts to approximately $50 \%$ in the first year 
(Ațýk and Katkat 2010, Gondek 2012). Hence, utilization of nitrogen from municipal sewage sludge by spring barley was assumed in the field experiment to be at a level of approximately $60 \mathrm{~kg} \cdot \mathrm{ha}^{-1}$, which was comparable with a dose of this element in the control treatment (1). Additionally, in treatment 2 (with the sludge), mineral fertilization was supplemented with phosphorus and potassium to the level applied in the control treatment (1).

In the third decade of March, "Rataj" cultivar spring barley was sown at a density of 400 germinating grains per $1 \mathrm{~m}^{2}$. Barley harvest took place in the second decade of August.

\section{Methodology of the research}

Samples of plant and soil material from 4 representative areas covering $15 \mathrm{~m}^{2}$ were collected from each production field: control (1) and with municipal sewage sludge (2). Soil samples were collected from a $0-25 \mathrm{~cm}$ layer. Once the spring barley samples were collected, the plant material was dried in a forced air circulation dryer at $105^{\circ} \mathrm{C}$, according to the widely adopted methodology of chemical-agricultural analysis. After drying of the plant material samples, the yield of the absolutely dry matter of spring barley grain and straw was determined. The samples were then subjected to dry mineralization in a muffle furnace at $600^{\circ} \mathrm{C}$ (Ostrowska et al. 1991).

The soil material was dried in a forced air circulation dryer at $70^{\circ} \mathrm{C}$. After drying, $\mathrm{pH}$ was determined in the soil material, by potentiometric method, in 1 $\mathrm{mol} \cdot \mathrm{dm}^{-3} \mathrm{KCl}$, organic carbon content was determined by Tiurin method, total nitrogen content - by Kjeldahl method, the content of available phosphorus and potassium - by Egner-Riehm method, and the content of available magnesium - by Schachtschabel method. The content of macronutrients $(\mathrm{Na}, \mathrm{K}, \mathrm{Mg}, \mathrm{Ca}, \mathrm{P})$ was determined after digesting the samples in a mixture of concentrated acids: $\mathrm{HNO}_{3}$ and $\mathrm{HClO}_{4},(3: 2, v / v)$.

After mineralization of the plant and soil material, the content of the elements was determined using ICP-AES spectrometer (Jones and Case 1990).

Determination in each of the studied samples was done in triplicate. The accuracy of the analytical method was verified against certified reference materials and standard solutions: CRM IAEA / V 10 hay (International Atomic Energy Agency), ERM - CD281 - rye grass, BCR-129 - Hay Powder (Institute for Reference Materials and Measurements), CRM 023-050 - heavy metals - sandy clay 7 (RT Corporation).

The laboratory test results were subjected to a statistical analysis using analysis of variance. Significance of differences between means were determined separately for grains and straw, using Tuckey test at a significance level of $\alpha \leq 0.05$.

The following parameters were assumed as the basis for determining the uptake of macronutrients by spring barley:

1. Yield (Y);

2. Content of macronutrients in grains and straw (C);

3. Uptake of macronutrients (U) by barley was calculated as a product of dry matter yield $(\mathrm{Y})$ and the content $(\mathrm{C})$ of the element, according to the formula: $\mathrm{U}=\mathrm{Y} \cdot \mathrm{C}$.

This paper presents the utilization of macronutrients by spring barley, which is defined as the percentage share of the amount of an element taken up by the plan $(\mathrm{U})$ in the total amount of this element introduced into soil together with municipal sewage sludge. This paper also presents quantitative ratios between the studied nutrients in spring barley biomass. Mass ratios for $\mathrm{K}: \mathrm{Na}, \mathrm{Ca}: \mathrm{Mg}$ and $\mathrm{Ca}: \mathrm{P}$, as well as equivalent ratios for $\mathrm{K}:(\mathrm{Ca}+\mathrm{Mg}), \mathrm{K}: \mathrm{Mg}$ and $\mathrm{K}: \mathrm{Ca}$ were calculated.

\section{RESULTS AND DISCUSSION}

\section{Basic soil properties and their changes after application of sewage sludge}

Application of municipal sewage sludge under spring barley at a dose of $5.34 \mathrm{Mg} \cdot \mathrm{ha}^{-1} \mathrm{DM}$ per hectare caused an increase in the content of organic carbon, total nitrogen and available phosphorus, potassium and magnesium (Table 2). The increase in the content of macroelements in the soil under the influence of sewage sludge was not statistically significant, but improved soil fertility, which was manifested in the growth of yields of barley cultivated in the experiment and has been confirmed by other authors (Flis-Bujak et al. 1986, Fisher et al. 2011). The field experiment showed that application of municipal sewage sludge did not have a significant effect on the decrease in soil $\mathrm{pH}$ (Table 2). Other authors have shown in their

TABLE 2. Chemical properties of soil from experimental plots after experiment

\begin{tabular}{cclllll}
\hline $\begin{array}{c}\text { Treat- } \\
\text { ment }\end{array}$ & $\mathrm{pH}_{\mathrm{KCl}}$ & $\mathrm{C}$ & $\mathrm{N}$ & $\mathrm{P}$ & $\mathrm{K}$ & $\mathrm{Mg}$ \\
\cline { 2 - 6 } & & total & \multicolumn{4}{l}{ available forms } \\
\cline { 2 - 6 } & & $\mathrm{g} \cdot \mathrm{kg} \mathrm{DM}$ & $\mathrm{mg} \cdot \mathrm{kg}^{-1}$ & $\mathrm{DM}$ \\
\hline 1 & $7.0 \mathrm{a}$ & $21.0 \mathrm{a}$ & $1.1 \mathrm{a}$ & $12.7 \mathrm{a}$ & $24.0 \mathrm{a}$ & $29.8 \mathrm{a}$ \\
\hline 2 & $6.9 \mathrm{a}$ & $21.2 \mathrm{a}$ & $1.2 \mathrm{a}$ & $12.9 \mathrm{a}$ & $24.5 \mathrm{a}$ & $30.5 \mathrm{a}$ \\
\hline
\end{tabular}

* values labeled with the same letters do not differ significantly among themselves according to Tukey's test, at a significance level of $\alpha \leq 0.05$. 
studies that application of municipal sewage sludge for fertilization caused an increase in soil acidity, which results from mineralization of organic matter (Moreno et al. 2003, Shaheen et al. 2014). Authors also confirm that application of municipal sewage sludge to soil has a positive effect on the increase in the content of organic carbon, total nitrogen and available forms of macroelements. Studies conducted by Gondek (2012), Wieczorek (2013), Kołodziej et al. (2016) confirmed the positive effect of municipal sewage sludge on the improvement of soil chemical properties and biological activity.

\section{Spring barley yield}

The conducted research shows that municipal sewage sludge had a significant effect on the increase in spring barley yield.

Grain and straw yield from the control treatment amounted to 4.20 and $3.10 \mathrm{Mg} \cdot \mathrm{ha}^{-1} \mathrm{DM}$, respectively, whereas grain and straw yield obtained from the treatment fertilized with sewage sludge amounted to 4.80 and $3.50 \mathrm{Mg} \cdot \mathrm{ha}^{-1} \mathrm{DM}$, respectively. The conducted research shows that application of municipal sewage sludge for fertilization increased the grain and straw yield by 14.2 and $12.9 \%$, respectively, in relation to the control treatment. In their research, Gondek (2012) and Wieczorek (2013) also confirmed the effect of municipal sewage sludge on the increase in yield of cereals.

The primary factor that influenced spring barley yielding was nitrogen coming from the municipal sewage sludge applied. The applied dose of municipal sewage sludge (5.34 Mg $\left.\cdot \mathrm{ha}^{-1} \mathrm{DM}\right)$ met the nutrient requirements, taking into account the use of nitrogen by spring barley. Along with the applied dose (5.34 $\mathrm{Mg} \cdot \mathrm{ha}^{-1}$ of sewage sludge DM), more than $118 \mathrm{~kg}$ $\mathrm{N} \cdot \mathrm{ha}^{-1}$ was introduced. Based on literature, it is assumed that the use of nitrogen from municipal sewage sludge by spring barley amounted to approximately $50 \%$, which constituted $60 \mathrm{~kg} \mathrm{~N} \cdot \mathrm{ha}^{-1}$ (Gondek 2012). In addition to nitrogen use, the sewage sludge improved soil chemical properties, and thereby had an intermediate effect on the increase in spring barley yield compared with the control treatment in which only mineral fertilizers were used.

\section{Content of macroelements in spring barley}

Chemical composition of plants depends on environmental factors (temperature, solar radiation, amount of precipitation, soil conditions), on the level of mineral, natural (manure, slurry) and organic fertilization (Pisulewska et al. 2009, Ahmed et al. 2010). The content of macronutrients and micronutrients is determined by the analyzed part of plant (Casado-Vela 2006, Jasiewicz et al. 2006). The content of the studied macroelements in spring barley depended on treatment and on the part of the plant (Table 3). Application of municipal sewage sludge to soil caused an increase in the content of macronutrients in barley yield. In the conducted research, differences in nutrient concentrations in individual parts of spring barley were also observed. Spring barley grains were found to have a higher content of $\mathrm{N}, \mathrm{P}$ and $\mathrm{Mg}$, whereas straw had a higher content of $\mathrm{K}, \mathrm{Na}$ and $\mathrm{Ca}$ (Table 3 ). Research conducted by Pisulewska et al. (2009) showed similarly that more $\mathrm{N}, \mathrm{P}$ and $\mathrm{Mg}$ is accumulated in grains of cereals than in straw.

Depending on chemical composition, spring barley grain is used for consumption or feed. Over $75 \%$ of spring barley cultivated in Poland is used for feed purposes (Statistical Yearbook of Agriculture 2015). It is assumed that feed of optimum quality should contain approximately $15-30 \mathrm{~g} \mathrm{~N}, 3 \mathrm{~g} \mathrm{P}, 17-20 \mathrm{~g} \mathrm{~K}$,
TABLE 3. Content and uptake of macronutrients by spring barley

\begin{tabular}{llllllll}
\hline \multirow{2}{*}{$\begin{array}{l}\text { Treat- Part of } \\
\text { ment }\end{array}$} & plants & $\mathrm{N}$ & $\mathrm{P}$ & $\mathrm{K}$ & $\mathrm{Na}$ & $\mathrm{Ca}$ & $\mathrm{Mg}$ \\
\cline { 2 - 7 } & \multicolumn{6}{l}{ Content of macroelements $\left(\mathrm{g} \cdot \mathrm{g}^{-1} \mathrm{DM}\right)$} \\
\hline 1 & Grain & $8.52 \mathrm{a}^{*}$ & $4.20 \mathrm{a}$ & $5.59 \mathrm{a}$ & $1.3 \mathrm{a}$ & $0.9 \mathrm{a}$ & $1.5 \mathrm{a}$ \\
2 & & $8.52 \mathrm{a}^{*}$ & $4.20 \mathrm{a}$ & $5.59 \mathrm{a}$ & $1.3 \mathrm{a}$ & $0.9 \mathrm{a}$ & $1.5 \mathrm{a}$ \\
\hline 1 & Straw & $1.74 \mathrm{a}$ & $1.10 \mathrm{a}$ & $16.50 \mathrm{a}$ & $1.5 \mathrm{a}$ & $5.9 \mathrm{a}$ & $1.2 \mathrm{a}$ \\
& & $2.56 \mathrm{~b}$ & $1.40 \mathrm{~b}$ & $17.10 \mathrm{a}$ & $1.7 \mathrm{~b}$ & $6.2 \mathrm{~b}$ & $1.4 \mathrm{a}$ \\
\hline \multicolumn{7}{l}{ Uptake of macroelements $\left({\left.\mathrm{kg} \cdot \mathrm{ha}^{-1}\right)}\right.$} \\
\hline 1 & Grain & $35.84 \mathrm{a}$ & $17.63 \mathrm{a}$ & $23.52 \mathrm{a}$ & $4.64 \mathrm{a}$ & $3.80 \mathrm{a}$ & $6.31 \mathrm{a}$ \\
2 & & $41.55 \mathrm{~b}$ & $23.26 \mathrm{~b}$ & $27.39 \mathrm{a}$ & $5.95 \mathrm{~b}$ & $5.28 \mathrm{~b}$ & $8.15 \mathrm{~b}$ \\
\hline 1 & Straw & $5.37 \mathrm{a}$ & $3.40 \mathrm{a}$ & $51.30 \mathrm{a}$ & $4.47 \mathrm{a}$ & $18.28 \mathrm{a}$ & $3.71 \mathrm{a}$ \\
2 & & $8.96 \mathrm{~b}$ & $4.91 \mathrm{~b}$ & $59.97 \mathrm{a}$ & $6.70 \mathrm{~b}$ & $21.72 \mathrm{~b}$ & $4.91 \mathrm{~b}$ \\
\hline
\end{tabular}

* values labeled with the same letters do not differ significantly among themselves according to Tukey's test, at a significance level of $\alpha \leq 0.05$. 
$7 \mathrm{~g} \mathrm{Ca}, 3 \mathrm{~g} \mathrm{Mg}$, and $1.5-2.5 \mathrm{~g} \mathrm{Na} \cdot \mathrm{kg}^{-1} \mathrm{DM}(\mathrm{Czuba}$ and Mazur 1988, Falkowski et al. 2000). When estimating the feed suitability of collected spring barley grain, it needs to be stated that phosphorus content in the grain was within the optimal value range, whereas the content of $\mathrm{Ca}, \mathrm{K}, \mathrm{Mg}$ and $\mathrm{Na}$ was lower than the optimal value.

The optimal content of $\mathrm{K}$ was observed in straw of spring barley grown on the treatment with sewage sludge. However, mineral fertilization, not the applied municipal sewage sludge, was the determinative factor that influenced the content of this nutrient in straw. When investigating the content of $\mathrm{Ca}$ in straw, it was observed that application of municipal sewage sludge in fertilization had a significant effect on the increase in its content. Ca content in this part of the plant was within optimal value range. Casado-Vela et al. (2006) and Singh and Agrawal (2008) confirm that municipal sewage sludge used for fertilizing purposes is a valuable source of nutrients for cultivated plants.

\section{The uptake of macronutrients by spring barley}

Cereal plants are characterized by high nutrient requirements, therefore the uptake of macronutrients by these plants is generally high (Mackowiak et al. 2011). Depending on the fertilization treatment, the uptake of macronutrients by spring barley was varied (Table 3). A significantly positive effect of municipal sewage sludge on the uptake of these elements was observed in the conducted research. From the field fertilized with sludge, more $\mathrm{N}, \mathrm{P}, \mathrm{Mg}$ and $\mathrm{Na}$ was taken up along with barley grain, whereas along with barley straw - more K and Ca (Table 3). Spring barley (grain and straw), fertilized with sewage sludge, took up the most $\mathrm{K}\left(87.4 \mathrm{~kg} \cdot \mathrm{ha}^{-1}\right)$, followed by $\mathrm{N}(50.5$ $\left.\mathrm{kg} \cdot \mathrm{ha}^{-1}\right), \mathrm{P}\left(28.2 \mathrm{~kg} \cdot \mathrm{ha}^{-1}\right), \mathrm{Ca}\left(27.0 \mathrm{~kg} \cdot \mathrm{ha}^{-1}\right), \mathrm{Mg}(13.1$ $\left.\mathrm{kg} \cdot \mathrm{ha}^{-1}\right)$, and the least $\mathrm{Na}\left(12.7 \mathrm{~kg} \cdot \mathrm{ha}^{-1}\right)$. The increase in the amount of macronutrients taken up by barley was determined by mineral and organic fertilization as well as by the content of nutrients in the soil. Singh and Agrawal (2008) as well as Gondek (2012) and
Wieczorek (2013) also showed a significant effect of fertilization with municipal sewage sludge on the increase in the uptake of macroelements by cereals.

\section{The use of macronutrients by spring barley}

The presented nutrient utilization is the percentage share of element uptake by barley in relation to the amount of elements introduced to soil along with municipal sewage sludge. Utilization of these nutrients by spring barley depended on their amount introduced along with the sewage sludge dose. $118.9 \mathrm{~kg} \mathrm{~N}, 19.5 \mathrm{~kg}$ $\mathrm{P}, 13.6 \mathrm{~kg} \mathrm{~K}, 5.9 \mathrm{~kg} \mathrm{Na}, 526.6 \mathrm{~kg} \mathrm{Ca}, 25.7 \mathrm{~kg} \cdot \mathrm{ha}^{-1}$ were introduced to the soil with the dose of 5.34 $\mathrm{Mg} \cdot \mathrm{ha}^{-1} \mathrm{DM}$ of municipal sewage sludge. Utilization of $\mathrm{N}, \mathrm{Mg}$ and $\mathrm{Ca}$ from municipal sewage sludge by spring barley was at a level of 43, 50 and $5 \%$ of the amount introduced with the waste, whereas utilization of $\mathrm{P}, \mathrm{K}$ and $\mathrm{Na}$ by spring barley was significantly higher than the amounts introduced with sewage sludge. The municipal sewage sludge applied at a dose of 5.34 $\mathrm{Mg} \cdot \mathrm{ha}^{-1} \mathrm{DM}$ ) did not cover the total uptake of $\mathrm{P}, \mathrm{K}$, Na by spring barley. Therefore, when municipal sewage sludge was used in cereal cultivation, macronutrients were supplemented with mineral fertilizers (Gondek 2012, Pisulewska et al. 2012, Kołodziej et al. 2015).

\section{Ratios between elements in spring barley}

Interrelationships between elements in plants constitute an important qualitative aspect in terms of using them for feed purposes (Mackowiak et al. 2011, Witkowicz et al. 2015). This paper presents the ratios between elements present in the harvested biomass of spring barley (Table 4). In the experiment, a small range of variability of these ratios between macronutrients in grain and straw of the tested plant was observed. It was established that the analyzed ratios between elements were much greater in straw than in grain. Thus, it must be stated that spring barley grain,

TABLE 4. Ratios between macroelements in spring barley

\begin{tabular}{llcccccc}
\hline $\begin{array}{l}\text { Treat- } \\
\text { ment }\end{array}$ & $\begin{array}{l}\text { Part of } \\
\text { plant }\end{array}$ & $\mathrm{K}: \mathrm{Na}$ & $\mathrm{Ca}: \mathrm{Mg}$ & $\mathrm{Ca}: \mathrm{P}$ & $\mathrm{K}:(\mathrm{Ca}+\mathrm{Mg})$ & $\mathrm{K}: \mathrm{Mg}$ & $\mathrm{K}: \mathrm{Ca}$ \\
\hline 1 & Grain & $4.31 \mathrm{a}^{*}$ & $0.75 \mathrm{a}$ & $0.21 \mathrm{a}$ & $0.85 \mathrm{a}$ & $1.16 \mathrm{a}$ & $0.36 \mathrm{a}$ \\
2 & & $4.07 \mathrm{~b}$ & $0.79 \mathrm{a}$ & $0.23 \mathrm{a}$ & $0.75 \mathrm{a}$ & $1.04 \mathrm{a}$ & $0.40 \mathrm{a}$ \\
\hline 1 & Straw & $11.00 \mathrm{a}$ & $4.92 \mathrm{a}$ & $5.36 \mathrm{a}$ & $1.07 \mathrm{a}$ & $4.27 \mathrm{a}$ & $2.02 \mathrm{a}$ \\
2 & & $10.06 \mathrm{~b}$ & $4.43 \mathrm{a}$ & $4.43 \mathrm{~b}$ & $1.03 \mathrm{a}$ & $3.79 \mathrm{~b}$ & $1.87 \mathrm{a}$ \\
\hline
\end{tabular}

* values labeled with the same letters do not differ significantly among themselves according to Tukey's test, at a significance level of $\alpha \leq 0.05$. 
regardless of treatment (type of fertilization), was characterized by stable ratios between these elements.

The conducted research shows that the applied municipal sewage sludge had an effect on the value of ratios between the determined elements. Application of municipal sewage sludge in spring barley cultivation resulted in a reduction of the value of $\mathrm{K}: \mathrm{Na}$, $\mathrm{K}:(\mathrm{Ca}+\mathrm{Mg}), \mathrm{K}: \mathrm{Mg}$ ratios in spring barley grain. Sewage sludge increased the values of $\mathrm{Ca}: \mathrm{Mg}, \mathrm{Ca}$ and $\mathrm{K}: \mathrm{Ca}$ ratios in spring barley grain compared with grain obtained from the control treatments. Application of municipal sewage sludge resulted in a reduction of the value of $\mathrm{K}: \mathrm{Na}, \mathrm{Ca}: \mathrm{Mg}, \mathrm{Ca}: \mathrm{P}, \mathrm{K}+(\mathrm{Ca}+\mathrm{Mg}), \mathrm{K}: \mathrm{Mg}$, $\mathrm{K}: \mathrm{Ca}$ ratios in spring barley straw.

The obtained biomass of spring barley was evaluated based on criteria of the feed nutrient value, according to which the optimal ratios of $\mathrm{K}: \mathrm{Na}, \mathrm{K}:(\mathrm{Ca}+\mathrm{Mg})$, $\mathrm{K}: \mathrm{Mg}, \mathrm{K}: \mathrm{Ca}, \mathrm{Ca}: \mathrm{Mg}$ and $\mathrm{Ca}: \mathrm{P}$ should amount to $10: 1$; 1.62-2.2:1; 6:1, 2:1,2-3:1 and 2:1, respectively (Puls 1994, Mackowiak et al. 2011, Poutanen et al. 2014). While evaluating spring barley grain, it was established that the analyzed values of ratios between elements were below the optimal value. Different ratios were observed in spring barley straw. Values of $\mathrm{K}: \mathrm{Na}$ and $\mathrm{K}: \mathrm{Ca}$ ratios in this part of the plant were within optimal range. The following values of $\mathrm{Ca}: \mathrm{Mg}, \mathrm{Ca}, \mathrm{K}: \mathrm{Mg}$ ratios in spring barley straw were above the optimal value, whereas value of $\mathrm{K}:(\mathrm{Ca}+\mathrm{Mg})$ ratio in spring barley straw was below the optimal value. Other authors' studies (Gondek 2012, Poutanen et al. 2014) have confirmed the effect of municipal sewage sludge on the values of the ratios between macronutrients in cereal grain.

\section{CONCLUSIONS}

1. Municipal sewage sludge enriched the soil in organic substance, total nitrogen, and in available forms of phosphorus, potassium and magnesium.

2. Application of municipal sewage sludge at a dose of $5.34 \mathrm{Mg} \cdot \mathrm{ha}^{-1} \mathrm{DM}$, which corresponded to 24 $\mathrm{Mg}$ of fresh matter per hectare, increased the biomass yield of spring barley by $13-14 \%$ in relation to the treatment fertilized only with mineral fertilizers.

3. Fertilization with sewage sludge stimulated the uptake and accumulation of macronutrients in grain and straw of spring barley compared with the treatment fertilized only with mineral fertilizers.

4. Municipal sewage sludge had a significant effect on the higher uptake of macronutrients by spring barley compared with the treatment fertilized only with mineral fertilizers.

5. Utilization of $\mathrm{N}, \mathrm{Mg}$ and $\mathrm{Ca}$ from municipal sewage sludge by spring barley was at a level of 43,50 and $5 \%$ of the amount introduced with the organic waste.

6. Ratios between elements differed depending on the index part of the plant. Ratios between elements in spring barley straw were within the optimal limit, that is why straw is recommended to be used for feed purposes.

\section{REFERENCES}

Act on waste, 2012. Act on wastes dated 14 December 2012. Journal of Laws of Poland. No O, Item 21.

Ahmed H.Kh., Fawy H.A., Abdel-Hady E.S., 2010. Study of sewage sludge use in agriculture and its effect on plant and soil. Agriculture and Biology Journal of North America 1(5): 1044-1049.

Alvarenga P., Mourinha C., Farto M., Santos T., Palma P., Sengo J., Morais M.C., Cunha-Queda C., 2015. Sewage sludge, compost and other representative organic wastes as agricultural soil amendments: Benefits versus limiting factors. Waste Management 40: 44-52.

Aţýk B.B., Katkat A.V., 2010. Evaluation of wastewater sludge for possible agricultural use. Environmental Engineering and Management Journal 10, 6: 819-826.

Bauman-Kaszubska H., Sikorski M., 2008. The possibilities of agricultural and natural use of sewage sludge on the example of chosen objects. Advances of Agricultural Sciences Problem Issues 526: 303-310 (in Polish).

Bień J., Neczaj E., Worwag M., Grosser A., Nowak D., Milczarek M., Janik M., 2011. Directions management of sludge in Poland after 2013. Engineering and Protection of Environment 14, 4: 375-384 (in Polish).

Casado-Vela J., Sellés S., Navarro J., Bustamante M.A., Mataix J., Guerrero C., Gomez I., 2006. Evaluation of composted sewage sludge as nutritional source for horticultural soils. Waste Management 26: 946-952.

Catalogue of waste, 2014. Regulation of the Minister of the Natural Environment on catalogue of wastes dated 9 December 2014. Journal of Laws of Poland, Item 1923.

Czuba R., Mazur T., 1988. Wpływ nawożenia na jakość plonów. PWN, Warszawa: ss. 360.

Environment, 2015. Statistical Information and Elaborations. Warsaw, GUS: pp. 565 (in Polish).

Falkowski M., Kukułka I., Kozłowski S., 2000. Właściwości chemiczne roślin łąkowych. Wydawnictwo AR Poznań: ss. 132.

Fischer T.B., Potter K., Donaldson S., Scott T., 2011. Municipal waste management strategies, strategic environmental assessment and the consideration of climate change in England. Journal of Environmental Assessment Policy and Management 13(4): 541-565.

Flis-Bujak M., Turski R., Baran S., 1986. Wpływ osadu ściekowego na przemiany związków próchnicznych w bielicowej glebie piaskowej. Roczniki Gleboznawcze - Soil Science Annual 37(2/3): 187-194.

Fytili D., Zabaniotou A., 2008. Utilization of sewage sludge in EU application of old and new methods - a review. Renewable and Sustainable Energy Reviews 12(1): 116-140.

Gondek K., 2012. Effect of fertilization with farmyard manure, municipal sewage sludge and compost from biodegradable waste on yield and mineral composition of spring wheat grain. Journal of Elementology 2: 231-245. 
Jasiewicz C., Antonkiewicz J., Baran A., 2006. Influence of organic fertilizers on heavy metal content in tall oat grass. Ecological Chemistry and Engineering A, 13(9): 915-923.

Jones J.B., Case V.W., 1990. Soil testing and plant analysis. $3^{\text {rd }}$ ed. Soil Science Society of America SSSA, Chapter 15.

Kelessidis A., Stasinakis A.S., 2012. Comparative study of the methods used for treatment and final disposal of sewage sludge in European countries. Waste Management 32(6): 1186-1195.

Kołodziej B., Antonkiewicz J., Stachyra M., Bielińska E.J., Wiśniewski J., Luchowska K., Kwiatkowski C., 2015. Use of sewage sludge in bioenergy production - A case study on the effects on sorghum biomass production. European Journal of Agronomy 69: 63-74.

Kołodziej B., Antonkiewicz J., Sugier D., 2016. Miscanthus $\times$ giganteus as a biomass feedstock grown on municipal sewage sludge. Industrial Crops and Products 81: 72-82.

Mackowiak C.L, Myer R.O, Blount A.R, Foster J.L, Barnett R.D., 2011. Yield and mineral concentration of southeastern United States oat cultivars used for forage. Journal of Plant Nutrition 34(12): 1828-1842.

Moreno J.L., Garcia C., Hernandez T., 2003. Toxic effect of cadmium and nickel on soil enzymes and the influence of adding sewage sludge. European Journal of Soil Science 54(2): 377-386.

Ostrowska A., Gawliński S., Szczubiałka Z., 1991. Methods of analysis and assessment of soil and plant properties. A Catalgoue. Publisher: Institute of Environmental Protection - National Research Institute, Warsaw: pp. 334 (in Polish).

Petruzzelli G., Pedron F., Grifoni M., Pera A., Rosellini I., Pezzarossa B., 2015. Effect of lime stabilization on E.coli destruction and heavy metal bioavailability in sewage sludge for agricultural utilization. World Academy of Science, Engineering and Technology, International Journal of Biological, Biomolecular, Agricultural, Food and Biotechnological Engineering 9(6): 593-598.

Pisulewska E., Poradowski R., Antonkiewicz J., Witkowicz R., 2009. The effect of variable mineral fertilization on yield and grain mineral composition of covered and naked oat cultivars. Journal of Elementology 14(4): 763-772.
Poutanen K., Sozer N., Valle G.D., 2014. How can technology help to deliver more of grain in cereal foods for healthy diet? Journal of Cereal Science 59: 327-336.

Puls R., 1994. Mineral levels in animal health. Diagnostic data. Sherpa International, Clearbrook, BC.

Regulation, 2015. Regulation of the Minister of the Natural Environment on municipal sewage sludge dated 6 February 2015. Journal of Laws of Poland, Item 257.

Shaheen S.M., Shams M.S., Ibrahim S.M., Elbehiry F.A., Antoniadis V., Hooda P.S., 2014. Stabilization of sewage sludge by using various by-products: Effects on soil properties, biomass production, and bioavailability of copper and zinc. Water, Air, Soil Pollution 225(7): 1-13.

Singh R.P., Agrawal M., 2008. Potential benefits and risks of land application of sewage sludge. Waste Management 28: $347-358$

Soriano-Disla J.M., Gómez I., Navarro-Pedreńo J., Jordán M.M., 2014. The transfer of heavy metals to barley plants from soils amended with sewage sludge with different heavy metal burdens. Journal of Soils and Sediments 14(4): 687-696.

Statistical Yearbook of Agriculture, 2015. Central Statistical Office, Warsaw: pp. 456 (in Polish).

Systematyka gleb Polski (Polish Soil Classification), 2011. Roczniki Gleboznawcze - Soil Science Annual 62(3): 1-193.

Wieczorek J., 2013. Wartość nawozowa komunalnych osadów ściekowych oraz ich wpływ na właściwości fizykochemiczne i aktywność biologiczną gleby. Zeszyty Naukowe UR w Krakowie, Seria Rozprawy 503, 380: ss. 120.

Wieczorek J., Frączek K., 2013. Assessment of possibility of agricultural use of municipal sewage sludge generated in selected small sewage treatment plants from Kraków district. Journal of Ecological Engineering 14(2): 36-42.

Witkowicz R., Antonkiewicz J., Pisulewska E., Bogocz D., 2015. The impact of agronomic factors on the content of selected microelements in naked oat (Avena sativa ver. nuda) grain. Ecological Chemistry and Engineering A 22(2): 239-250.

Received: April 9, 2016

Accepted: October 14, 2016

\section{Wpływ komunalnego osadu ściekowego na skład chemiczny jęczmienia jarego}

Streszczenie: Ze względu na przeważający udział gleb lekkich w Polsce istnieje potrzeba poprawy ich właściwości fizycznych, chemicznych i biologicznych. Ponadto, w wyniku spadku pogłowia zwierząt gospodarskich obserwuje się obniżenie wielkości produkcji nawozów naturalnych. Niska produkcja nawozów naturalnych przemawia za rolniczym wykorzystaniem komunalnych osadów ściekowych w Polsce. Komunalne osady ściekowe w swoim składzie zawierają duże ilości makroelementów niezbędnych dla roślin. Odpad ten zawiera także znacząca ilość substancji organicznej. Właściwości chemiczne, w tym duża zawartość azotu, fosforu, a często i wapnia, przemawiają za przyrodniczym wykorzystaniem komunalnych osadów ściekowych. Rosnące wymagania w zakresie ochrony środowiska powodują konieczność oceny skutków stosowania odpadów organicznych do celów nawozowych. W gospodarstwie rolnym zlokalizowanym w gminie Iwanowice (województwo małopolskie) zastosowano komunalny osad ściekowy pod uprawę jęczmienia jarego. Glebę, na której zastosowano komunalne osady ściekowe, zaliczono do kategorii gleb ciężkich o odczynie obojętnym. Oceniając zawartość przyswajalnych składników (P, K, Mg) w glebie stwierdzono ich niską zawartość. Po zastosowaniu

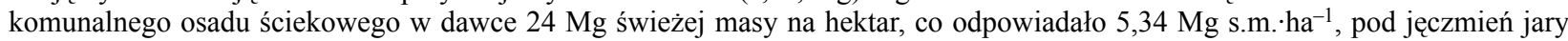
zaobserwowano korzystne zmiany właściwości chemicznych gleby. Stwierdzono wzrost zasobności gleby w węgiel organiczny, azot ogólny oraz wzrost zawartości przyswajalnych form fosforu, potasu i magnezu. Na podstawie wyników przeprowadzonych analiz chemicznych, stwierdzono, że biomasa jęczmienia jarego nawożona osadem ściekowym zawierała więcej makroskładników pokarmowych (N, P, K, Na, Ca i Mg), co poprawiało jej wartość paszową. W doświadczeniu łanowym wykazano, że aplikacja komunalnego osadu ściekowego wpłynęła na zwiększenie pobrania makroskładników pokarmowych przez jęczmień jary.

Słowa kluczowe: jęczmień jary, komunalny osad ściekowy, makroskładniki, zawartość, pobranie, stosunki pierwiastków 